\title{
A systematic process study is conducted to optimize the pre-processing parameters of Litchi slag
}

\author{
Chunhai Li ${ }^{1,2}$ a, Weidong Sun ${ }^{1}$,Zhiqun Liang ${ }^{1}$ \\ ${ }^{1}$ Institute of Light Industry and Food Engineering, Guangxi University, Nanning 530004, China \\ ${ }^{2}$ Guangdong University of Petrochemical Technology,Maoming,525000.China \\ agdmm0808@126.com
}

Keywords: fresh litchi; litchi slag; pretreatment; process study

Abstract. In this paper, we described the process study about the pre-processing parameters of litchi slag. After investigating the influence of single factor and the orthogonal experiments, we obtained the optimum process parameters. The optimum process conditions of cellulase hydrolysis is $\mathrm{X}_{1} 2 \mathrm{X}_{2} 3 \mathrm{X}_{3} 1 \mathrm{X}_{4} 2$ (hydrolysis temperature $50^{\circ} \mathrm{C}, \mathrm{pH}=4.0,2.0 \%$ of enzyme and hydrolysis $120 \mathrm{~m}$ ) to hydrolysate of Litchi slag. Under the optimum conditions, we can obtain the reducing sugar about $4.85 \pm 0.68 \%$ in hydrolysate of Litchi slag.

\section{Introduction}

Litchi slag is rich in cellulose, and cellulose is a polymer and composed by glucose, which can't be degraded by saccharomyces cerevisiae. In order to improve the utilization of nutrients in litchi slag by saccharomyces cerevisiae, we need to pre-process the litchi slag to increase the content of reducing sugar, to meet the needs of the growth of saccharomyces cerevisiae. Till now, the pre-processing methods of cellulose mainly include physical, chemical and biological methods. Physical method mainly using physical measures to process the raw materials, such as: crushing materials, heat treatment, microwave treatment and etc; Chemical method mainly using chemical reagents, such as alkali, acid, organic solvents, to process the material, which could make the frame structure of cellulose raw material loose and for subsequent processing; Biological method mainly using microorganisms or cellulase to degrade cellulose to small molecular compounds which can be ferment by saccharomyces cerevisiae. Among these methods, biological method with the advantage of safe, clean and low energy consumption and is the best way for the pretreatment of cellulose.[1-2] Herein, we report a simple biological method to pre-process the Litchi slag.

\section{Experiment content and method}

\section{Pretreatment process of Litchi slag}

Fresh litchi scraps - drying - slag crushing the slags to 60 mesh and then adding some $\mathrm{pH}=5.0$ citric acid and sodium citrate buffer $-100^{\circ} \mathrm{C}$ for $10 \mathrm{~m}$ - cool to room temperature, and adding suitable amount of cellulose[3] in the optimal conditions for $2.5 \mathrm{~h}$ - destroy the cellulase in the boiling water and for $15 \mathrm{~min}$ - cooling - centrifugal (3000 RPM, $30 \mathrm{~min}$ ) - the enzymolysis liquid.

\section{Single factor experiments}

We first screened the enzymatic hydrolysis conditions of cellulose to process the cellulose for its saccharify. We selected five levels of the substrate concentration: 5\%, 10\%, 15\%, 20\%, 25\%; With enzyme amount of $15 \mu \mathrm{g}, 30 \mu \mathrm{g}, 45 \mu \mathrm{g}, 60 \mu \mathrm{g}, 75 \mu \mathrm{g}$; $\mathrm{PH}=3.0,4.0,5.0,6.0,7.0$; Temperature: $40^{\circ} \mathrm{C}$, $45^{\circ} \mathrm{C}, 50^{\circ} \mathrm{C}, 55^{\circ} \mathrm{C}$ and $60^{\circ} \mathrm{C}$, to the each corresponding levels.

\section{The determination of reducing sugar content}

Based on the literature, the determination of reducing sugar content using the DNS(3,5-di nitro salicylic acid) method. 
The preparation of 3, 5-dinitro salicylic acid (DNS)

$182 \mathrm{~g}$ sodium potassium tartrate added brown reagent bottles and dissolved in $500 \mathrm{ml}$ hot water, then add $6.3 \mathrm{~g}$ DNS and $262 \mathrm{~mL} \mathrm{NaOH}(2 \mathrm{~mol} / \mathrm{L})$ solution, after dissolving adequately, add $5 \mathrm{~g}$ of sodium sulfite to make $1000 \mathrm{~mL}$, placed more than seven days to use.

The drawing of the standard curve

Accurately moving $1 \mathrm{mg} / \mathrm{ml}$ glucose standard solution of $0 \mathrm{~mL} 0.1 \mathrm{Ml}, 0.2 \mathrm{~mL}, 0.3 \mathrm{~mL}, 0.4 \mathrm{~mL}$ and $0.5 \mathrm{~mL}$ sitting in $0-5$ test tubes separately, and respectively adding $0.5 \mathrm{~mL}, 0.4 \mathrm{~mL}, 0.3 \mathrm{~mL}, 0.2 \mathrm{~mL}$ and $0.1 \mathrm{~mL}$ and $0 \mathrm{mLdistilled} \mathrm{water} \mathrm{to} 0-5$ test tubes. Then all the test tubes add DNS reagent $0.5 \mathrm{~mL}$, shake well, next, we treated them with boiling water bath for $5 \mathrm{~m}$ and then cooling the tubes to room temperature with ice water. Finnally, all the tubes add $4 \mathrm{~mL}$ of distilled water. Under the conditions of $540 \mathrm{~nm}$, using 0 tube as the standard, to determine the OD value of each tube. The standard curve of glucose is shown in figure 1 .

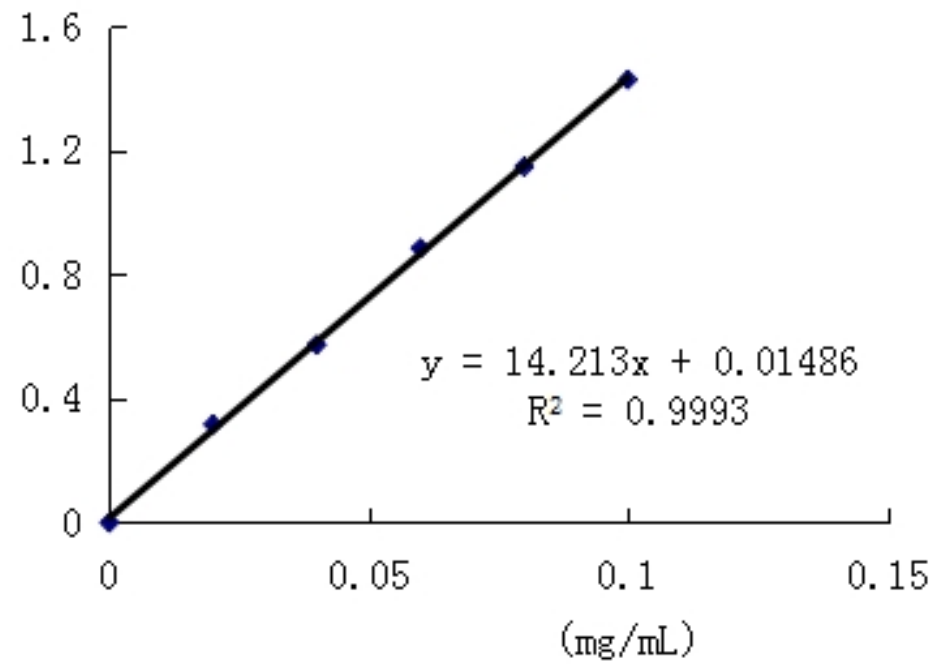

The detection of samples

Fig.1 Standard curve of glucose

Take $0.5 \mathrm{~mL}$ of the hydrolysate of each factor, then add $0.5 \mathrm{~mL}$ of the DNS reagent to each tube, shake well, treated them with boiling water bath for $5 \mathrm{~m}$ and then cooling the tubes to room temperature with ice water, and add $4 \mathrm{~mL}$ of distilled water to each tube to detect the absorbance values in $540 \mathrm{~nm}$ wavelength. Finally, Calculation of the reducing sugar content in the samples using the absorbance values.

Orthogonal experiment to optimize the enzymolysis technology

Tab. 1 Factors and levels of orthogonal test

\begin{tabular}{lllll}
\hline \multirow{2}{*}{ Level } & Factor & & & \\
\cline { 2 - 5 } & $\mathrm{X}_{1}\left({ }^{\circ} \mathrm{C}\right)$ & $\mathrm{X}_{2}(\%)$ & $\mathrm{X}_{3}(\min )$ & $\mathrm{pH}$ \\
\hline 1 & 45 & 1.5 & 90 & 4.5 \\
2 & 50 & 2.0 & 120 & 5.0 \\
3 & 55 & 2.5 & 150 & 5.5 \\
\hline
\end{tabular}

Based on the results of single factor experiments, we selected the enzymolysis temperature $\left(\mathrm{X}_{1}\right)$, the level of enzyme $\left(\mathrm{X}_{2}\right)$, the enzymolysis time $\left(\mathrm{X}_{3}\right)$, the $\mathrm{pH}$ value of hydrolysis $\left(\mathrm{X}_{4}\right)$, using the content of reducing sugar (Y) as the test index, to design the orthogonal experiment with four factors and three levels, and the factors, levels of enzymolysis technology, as shown in table 1.

Data analysis

Each experiment value is mean of three "repeatable" tests. The tested results underwent the analysis of variance by DPS software (version 3.01). $\mathrm{P}<0.05$ as the significant level of the experiment result. 


\section{Experimental results and discussion}

\section{The component analysis of Litchi slag}

The component results of Litchi slag is shown in table 2. The results indicated that Litchi slag containing large amounts of sugar, mainly include glucose, fructose and sucrose, which are all can be used to produce wine, alcohol, succinic acid, fruit vinegar and citric acid and other microbial products. Besides, Litchi slag also contains a lot of pectin, protein and 17 kinds of amino acids.

Table 2 The component of Litchi slag

\begin{tabular}{cccccc}
\hline Entry & Glucose & Fructose & Sucrose & Protein & Pectin \\
Mass fraction $(\%)$ & 2.87 & 16.67 & 15.79 & 3.99 & 12.48 \\
\hline
\end{tabular}

\section{Orthogonal test}

On the basis of single factor experiments (enzymolysis temperature $\left(\mathrm{X}_{1}\right)$, the level of enzyme $\left(\mathrm{X}_{2}\right)$, the enzymolysis time $\left(\mathrm{X}_{3}\right)$, the $\mathrm{pH}$ value of hydrolysis $\left(\mathrm{X}_{4}\right)$ ), we design the orthogonal experiments, the results are showed in table 3 .

Tab.3 The results of orthogonal test

\begin{tabular}{llllll}
\hline No. & $\mathrm{X}_{1}$ & $\mathrm{X}_{2}$ & $\mathrm{X}_{3}$ & $\mathrm{X}_{4}$ & $\begin{array}{l}\text { the content of } \\
\text { reducing sugar } \mathrm{Y}(\%)\end{array}$ \\
\hline 1 & $1(45)$ & $1(1.5)$ & $1(90)$ & $1(4.5)$ & 3.15 \\
2 & $1(45)$ & $2(2.0)$ & $2(120)$ & $2(5.0)$ & 2.14 \\
3 & $1(45)$ & $3(2.5)$ & $3(150)$ & $3(5.5)$ & 3.39 \\
4 & $2(50)$ & $1(1.5)$ & $2(120)$ & $3(5.5)$ & 3.21 \\
5 & $2(50)$ & $2(2.0)$ & $3(150)$ & $1(4.5)$ & 4.76 \\
6 & $2(50)$ & $3(2.5)$ & $1(90)$ & $2(5.0)$ & 4.79 \\
7 & $3(55)$ & $1(1.5)$ & $3(150)$ & $2(5.0)$ & 3.00 \\
8 & $3(55)$ & $2(2.0)$ & $1(90)$ & $3(5.5)$ & 3.60 \\
9 & $3(55)$ & $3(2.5)$ & $2(120)$ & $1(4.5)$ & 4.69 \\
K1 & 2.893 & 3.120 & 3.847 & 4.200 & \\
K2 & 4.253 & 3.500 & 3.347 & 3.310 & \\
\hline K3 & 3.763 & 4.290 & 3.717 & 3.400 & \\
Range analysis & 1.360 & 1.170 & 0.500 & 0.890 & \\
\hline
\end{tabular}

As shown in table 3, we found that the primary and secondary factors of influence to the litchi slag hydrolysis is: hydrolysis temperature $\left(\mathrm{X}_{1}\right)>$ enzyme dosage $\left(\mathrm{X}_{2}\right)>\mathrm{pH}$ value $\left(\mathrm{X}_{4}\right)>$ hydrolysis time $\left(\mathrm{X}_{3}\right)$. Besides, we also can be obtained from the orthogonal table, $\mathrm{K} 2$ is the biggest of factor $\mathrm{X}_{1}, \mathrm{~K} 3$ is the biggest of factor $X_{2}, K 1$ is the biggest of factor $X_{3}, K 1$ is the biggest of factors $X_{3}$ and $X_{4}$. Therefore, the optimum process conditions of cellulase hydrolysis is $\mathrm{X}_{1} 2 \mathrm{X}_{2} 3 \mathrm{X}_{3} 1 \mathrm{X}_{4} 2$, that is to say, the best hydrolysis conditions: hydrolysis temperature $50^{\circ} \mathrm{C}, \mathrm{pH}=4.0,2.0 \%$ of enzyme and hydrolysis $120 \mathrm{~m}$. Under this standard conditions, leading the content of reducing sugar to the maximum level in hydrolysate $(4.85 \pm 0.68 \%)$.

\section{Conclusion}

In summary, we have discovered the optimum process conditions of cellulase hydrolysis is $\mathrm{X}_{1} 2 \mathrm{X}_{2} 3 \mathrm{X}_{3} 1 \mathrm{X}_{4} 2$ : hydrolysis temperature $50^{\circ} \mathrm{C}, \mathrm{pH}=4.0,2.0 \%$ of enzyme and hydrolysis $120 \mathrm{~m}$, through investigating the influence of single factor and orthogonal experiments to the hydrolysate of Litchi slag using cellulase as the agent of enzymolysis. Under the optimum conditions, we can obtain the reducing sugar about $4.85 \pm 0.68 \%$ in hydrolysate of Litchi slag.

\section{References}

[1] L. M. Palmowski, J. A. Muller: Water Science and Technology Vol 41(2000), p. 155.

[2] M. J. Taherzadeh, K. Karimi: Molecular Sciences Vol 9(2008), p. 1621.

[3] C.Sanchez: Biotechnology Advances Vol 27(2009), p. 185. 